\title{
Peran Serta Masyarakat Di Kota Malang Berdasarkan UU No. 24 Tahun 1992 Dalam Pelaksanaan Otonomi Daerah
}

\author{
Musleh Harry, SH \\ Dosen Fakultas Syari'ah UIIS -Malang
}

\section{Abstract}

People strongly unge for a civil society as the reflection of democracy in which the people's great participation determine the success of the programs planned by government. The Constitutions No 241992 and No. 221999 show that people have the right to take a part in determining the programs. However, it is clearly seen that this civil right is not well accommodated. As the result, the developmental programs are not designed to meet their need and, even, create critical gaps. This social legal research is done to find out the effectiveness of application of the two above rules by paying more attention the causes of the low participation given by the informal workers (PKL) and ways how the local government applies two rules.

It turn out the government is not consistent in having law enforcement toward these people. This was caused by the fact that government considers these informal workers only have a temporal job. In addition, the government doesn't have a definite policy as result of reform euphoria

Ulul Albab, Vol. 4 No. 1, 2002 


\section{A. Latar Belakang}

Gagasan mengenai otonomi daerah dari waktu ke waktu dalam bentuk dan isi pada umumnya selalu berubah sesuai dengan konfigurasi dan peta kekuatan politik yang ada. Oleh karena itu otonomi daerah harus dipandang sebagai salah satu jalan yang bisa ditempuh untuk memperkuat eksistensi (peran serta) masyarakat. Dalam pelaksanaan otonomi daerah ada hal lain keberhasilan yang hendak dicapai adalah kedaulatan rakyat, keadilan, demokrasi dan kemajuan, atau penguatan peran serta masyarakat.

Secara tegas dalam Undang-Undang No 24 tahun 1992 tentang Penataan Ruang. Diperjelas lagi dalam Undang-undang No. 22 Tahun 1999 pasal 92 ayat (1) : "Dalam penyelenggaraan pembangunan kawasan perkotaan, Pemda perlu mengikutsertakan masyarakat dan pihak swasta". Pasal ini adalah upaya pemberdayaan masyarakat dalam pembangunan perkotaan.

Namun ironisnya, pelaksanaan penataan ruang selama ini, pada umumnya kurang melibatkan masyarakat. Pola pembangunan kota cenderung terpusat di tempat-tempat yang secara ekonomis strategis, sehingga mengakibatkan kelompok marginal semangkin terdesak ke daerah pinggiran kota dengan berbagai fasilitas minim yang jauh berbeda dengan kelompok masyarakat yang ekonominya tergolong kuat $^{1}$.

Swasta yang seharusnya menjadi mitra pemerintah dan masyarakat dalam proses penataan ruang belum mempunyai komitmen yang jelas terhadap visi kemitraan dalam penataan ruang. Sebagaimana dalam rekomendasi kebijakan hasil akhir Lokakarya Nasional " Kebijakan Tata Ruang Nasional dan Aspek Pertanahan dalam Perspektif Pertumbuhan dan Pemerataan" pada tanggal 9-10 Oktober 1995 di Bandung yang isinya antara lain:

1) Swasta sering kali terkesan mendikte misi alokasi pemanfaatan ruang yang biasanya direpresentasikan dalam bentuk pelanggaraan terhadap suatu rencana tata ruang

2) Sanksi terhadap pelanggaran tidak tegas dan tidak memberikan implikasi positif terhadap visi penata ruang yang telah di rencanakan

3) Masih terjadinya perpanjangan izin lokasi pemanfaatan ruang yang tidak sesuai dengan peraturan prundang-undangan yang berlaku. ${ }^{2}$. 
Padahal Undang-Undang No 24 Tahun 1992 menegaskan bahwa:"setiap orang mempunyai hak dan kewajiban di dalam penyusunan rencana tata ruang, pemanfaatan ruang dan pengendalian pemanfaatan ruang". Sedangkan bentuk peran serta masyarakat dalam penataan ruang di atur dalam PP. No 69 tahun 1996, salah satunya adalah: "pemberian masukan untuk menentukan arah pengembangan wilayah yang akan di capai, pemanfaatan ruang daratan, udara dan lautan berdasarkan peraturan perundang undangan, agama, adat atau kebiasaan yang berlaku". Namun sampai saat ini peraturan pelaksanaan yang mengatur tentang peran serta masyarakat, yakni belum ada mekanisme yang mengatur dan menjamin transparansi tentang peran serta masyarakat dalam penataan ruang serta tidak ada penanganan yang tegas bagi pelaku pelanggaran.

Masalah kota sangat kompleks memerlukan perencanaan terpadu agar pertumbuhan dan pengembangannya lebih terarah, seimbang dan serasi dengan tuntutan pendudukanya. Sebagaimana diatur dalam Undang-undang No. 22 tahun 1999 tentang Otoda dan Peraturan Menteri Dalam Negeri No. 4 tahun 1980 tentang Pedoman Penyusunan Rencana Kota. ${ }^{3}$

Kasus yang paling aktual, adalah pemanfaatan ruang adalah di Jalan Majapahit dan di depan Stasiun Kota Baru Malang dan sekitarnya yang dimanfaatkan oleh masyarakat (PKL) untuk kegiatan perdagangan. Pemanfaatan ruang tersebut, tidak saja secara yuridis bertentangan dengan rencana tata ruang, tetapi dari sisi estetika jelas mengurangi keindahan, kebersihan dan menimbulkan bahaya kemacetan serta dapat menimbulkan konflik kepentingan publik (publik interest) dan kepentingan individu (privat interest).

\section{B. Rumusan Masalah}

Permasalahan yang timbul, sebagai berikut:

1. Mengapa pola penggunaan ruang yang telah ditetapkan dalam Rencana Tata Ruang Wilayah (RTRW) dalam implementasi cenderung dikesampingkan?

2. Bagaimana peran serta masyarakat Pedagang Kaki Lima (PKL) di Kota Malang dalam pemanfaatan ruang yang sesuai dengan peruntukannya? 


\section{Musleh Hamy}

\section{Tujuan Studi}

Tujuan penelitian ini, yaitu :

1. Mendiskripsikan tentang sebab-sebab perlu penggunaan lahan (ruang) yang cenderung menyimpang dari pola penggunaan lahan (ruang) yang telah ditetapkan dalam rencana tata ruang wilayah (RTRW).

2. Mengambarkan sebab-sebab rendahnya peran serta masyarakat Pedagang Kaki Lima (PKL) dan kota Malang dalam pemanfaatan ruang.

\section{Studi Pustaka}

\section{Landasan Hukum Penataan Ruang}

Amanat Undang-Undang Dasar 1945 dalam pasal 33 ayat (3) yang harus dilaksanakan juga oleh pemerintah daerah dalam mengatur tata ruang diperkotaan. Kemudian dijabarkan lebih lanjut dalam pasal 2 UUPA tanggal 24 September 1960 , yang berbunyi :

Atas dasar ketentuan dalam pasal 33 ayat (3) Undang-Undang Dasar 1945 dan hal-hal sebagai yang dimaksud dalam pasal 1, bumi, air dan ruang angkasa, termasuk kekayaan alam yang terkandung di dalamnya itu pada tingkatan tertinggi dikuasai oleh Negara, sebagai organisasi kekuasaan seluruh rakyat.

Dua pesan kunci yang terkandung dalam pasal tersebut adalah negara menguasai berarti mengatur penggunaan, peruntukan dan alokasi lahan melalui perundang-undangan dan kebijakan tertulis lainnya, sedangkan diperuntukan bagi kemakmuran rakyai sebesam-besamya berarti alokasi lahan dari berbagai jenis fungsi yang dibutuhkan oleh seluruh lapisan masyarakat untuk dapat hidup secara layak. Wewenang pada hak menguasai dari negara digunakan untuk mencapai sebesar-besar kemakmuran rakyat dalam arti kebangsaan, kesejahteraan dan kemerdekaan dalam masyarakat dan negara hukum Indonesia yang merdeka, berdaulat, adil dan makmur

Penataan ruang mempunyai: Prinsip efisiensi menyatakan bahwa : ruang yang ada harus dimanfaatkan secara optimal sejalan dengan nilai ekonominya, sedangkan prinsip equity atau pemerataan menyatakan bahwa : pemanfaatan 
ruang harus memperhatikan nilai-nilai sosial, terutama untuk menjamin kemungkinan akses yang setara bagi masyarakat untuk memanfaatkan ruang sebagai sumber utama pembangunan'.

\section{Eksistensi Masyarakat Pedagang Kaki Lima (PKL) di Kota Malang}

Bermula dari krisis multidimensioal yang ditandai dengan krisis moniter, ambruknya dunia perbankan Indonesia, dan banyak perusahaan gulung tikar. Akibatnya banyak bank dan perusahaan yang mempe-HK-kan sebagian besar karyawannya, maka pengangguran semakin bertambah. Bagi masyarakat yang masih punya semangat untuk bekerja, mereka menjadi pedagang kecil ditempattempat yang mereka anggap dapat menjual barang dagangannya, yang biasa di sebut "Pedagang Kaki Lima” (PKL).

Untuk memahami realitas mengapa (PKL) masih saja berjualan yang tiap hari terus bertambah dan lokasinya terus semakin meluas pula, disebabkan: (a) pemda "tidak konsisten " di dalam menegakkan hukum (low enforcement) terhadap PKL, (b) rendahnya penegakan hukum (law enforcement).

\section{Peran serta Masyarakat Pedagang Kaki Lima (PKL) Dalam Penataan Ruang}

Peranan masyarakat sangat menentukan keberhasilan dan keseimbangan penataan ruang yang diinginkan. Karena masyarakat itu sendiri yang mengetahui kebutuhan berkenaan penataan ruang yang perlu diprioritaskan. peran serta masyarakat (PKL) harus sudah dimulai sejak perencanaan, pemanfaatan dan pengendalian pemanfaatan ruang.

Konsepsi peran serta masyarakat adalah sebuah proses yang mungkin membawa kewenangan yang menurut Heller dalam Muzakir ${ }^{6}$, digambarkan :

"Dua bentuk peran serta, yaitu : (a) peran serta grass root menunjuk pada pergerakan organisasi dan sosial diajukan oleh masyarakat yang me 2 milih metode dan tujuan adalah mereka, (b) peran serta Government Mandated (resmi), dimana peran serta masyarakat meliputi keperluan yang sah yang telah ada memberikan 
kesempatan bagi masukan masyarakat ke dalam sebuah kebijakan oleh sebuah agen pemerinntahan".

Konsep Heller tersebut, nampaknya sangat bersesuai dengan konsep peran serta dalam Undang-undang No. 24 Tahun 1992, yang bentuk dan tata cara pengaturannya tertuang dalam Peraturan Pemerintah (PP) No. 69 Tahun 1996. Dengan kata lain UU penataan ruang ini sangat responsip sekali, yaitu dengan menempatkan peran serta masyarakat dalam penataan ruang mulai dari proses penyusunan rencana tata ruang, pemanfaatan rencana tata ruang dan pengendalian rencana tata ruang.

Tiga alasan utama peran serta masyarakat mempunyai sifat yang penting, yaitu:

"Pertama, suatu alat guna memperoleh suatu informasi mengenai kondisi, kebutuhan dan sikap masyarakat. Kedua, masyarakat akan lebih mempercayai program pembangunannya jika mereka dilibatkan dalam proses persiapan dan perencanaannya, dan ketiga, merupakan suatu hak demokrasi bila masyarakat dilibatkan dalam pembangunan itu sendiri

Upaya menggerakkan peran serta masyarakat, menurut Passaribu dan Simanjutak $^{7}$ sangat diperlukan adanya : Pertama, pengkalisifikasian jenis peran serta. Kedua, peran serta ini perlu diwadahi. agar kegairahan berperan serta tidak semakin menipis bahkan hilang. Wadah peran serta merupakan semacam lembaga yang berbentuk : (a) wadah peran serta buah pikiran, (b) wadah peran serta tenaga, (c) wadah peran serta harta benda, (d) wadah peran serta ketrampilan.

\section{Kesadaran Hukum Masyarakat}

Di Indonesia masalah kesadaran hukum mendapat tempat yang sangat penting di dalam politik hukum nasional. Sebagaimana tercermin dalam Ketetapan MPR No. IV/MPR/1973 tentang GBHN.

Masalah kesadaran hukum masyarakat merupakan titik sentral. Karena kesadaran hukum masyarakat berperan penting untuk terciptanya tegaknya hukum, terbentuknya bangunan hukum yang bersih dan berwibawa. Unsur agar orang sadar terhadap hukum adalah adanya pengetahuan terhadap hukum yang merupakan proses awal timbul kesadaran masyarakat terhadap hukum. Tentunya harus dibarengi 
dengan ketaatan atau kepatuhan masyarakat terhadap hukum. Kelemahan kesadaran hukum masyarakat yang sering terjadi ialah tidak adanya komunikasi hukum. Sebagaimana menurut Friedman, dalam Munir?.

Persons menegaskan bahwa, agar fungsi hukum tersebut dapat berjalan dengan efektif, ada empat prasyarat dalam suatu sistem hukum, yaitu: (a) masalah legitimasi, (b) masalah interpretasi, (c) masalah sanksi baik jenis maupun lembaga yang menerapkannya, dan (d) masalah yuridiksi, penegakan norma-norma hukum ${ }^{\text {. }}$

\section{Bekerjanya Hukum Dalam Masyarakat}

Secara sosiologis, hukum merupakan lembaga kemasyarakatan. Hal ini disebabkan karena hukum bertujuan untuk memenuhi kebutuhan pokok dari para warga masyarakat, berfungsi sebagai pedoman masyarakat bertingkah laku, sebagai alat untuk menjaga keutuhan masyarakat dan sebagai sistem pengendalian sosial.

Bekerjanya hukum dalam masyarakat memerlukan beberapa tahap setelah hukum itu diciptakan, yaitu:

1. Harus ada pejabat yang ditetapkan dalam peraturan hukum tersebut

2. Harus ada orang-orang yang melakukan dari hukum itu

3. Orang-orang tersebut menetahui adanya peraturan hukum

4. Adanya kemauan dari orang-orang tersebut untuk berbuat.

Sekalipun hukum bersifat abstrak, tetapi hukum itu mampu mempengaruhi pilihan tindakan manusia. Menurut Seidman, hukum mempengaruhi pilihan tindakan manusia melalui dua cara, yaitu secara langsung dan tidak langsung. Pengaruh secara langsung terhadap tindakan manusia disebabkan beberapa karena (a) individu (manusia) merasa hukum itu merupakan perintah yang bersifat memaksa, (b) pengaruh hukum secara tidak langsung, karena individu memperhatikan dan mengikuti pola-pola perilaku yang dilakukan oleh orang lain secara berulang-ulang atau sudah melembaga dalam kehidupan masyarakat. ${ }^{10}$

\section{Otonomi Daerah Untuk Pemberdayaan Masyarakat.}

Issue otonomi yang kerkembang menjadi kebijakan otonomi daerah dapat dilihat dalam suatu konteks bagaimana perintahan mengeluarkan suatu kebijakan otonomi daerah, antara lain: Pertama, konteks global, Sejalan dengan perkembangan 
kapitalisme global, semakin dibutuhkan dua hal: (1) pembukaan pintu seluas-luasnya bagi globalisasi barang dan jasa, (2) mendorong langkah efisiensi dan efektivitas dalam kerja birokrasi pemerintahan, artinya harus menghilang skema kerja yang terlalu birokratis.

Kedua, konteks, nasional-lokal. Hal ini terkait dengan perubahan-perubahan langsung, yang memungkinkan berkembangnya kebijakan tersebut. Sebagaimana diketahui bahwa pemerintah Orde baru lahir dari situasi darurat. Skema darurat dijadikan dasar bagi: (a) kontrol yang ketat pada masyarakat, (b) kinerja pemerintah yang lebih bersifat ad hoc walaupun sudah ada repelita. Dalam kondisi yang darurat, sudah tentu dibutuhkan proses pengambilan kebijakan (keputusan) yang cepat dan terpusat $^{11}$.

Guna meningkatkan pemberdayaan (peran serta) masyarakat, maka dalam Undang-undang Otonomi daerah terutama dalam mengakomodir aspirasi masyarakat, yaitu:

1. Di setiap daerah harus dikembangkan otoritas keilmuan yang mampu mengidentifikasikan potensi alam di daerahnya.

2. Perlu dikembangkan Badan Penyelesaian Sengketa yang berasal dari sengketa pengelolaam sumber daya alam baik di tingkat daerah maupun nasional.

3. Perlu dikembangkan Dewan Kota, Dewan kabupaten dan Badan Perwakilan Desa yang benar-benar berfungsi sebagai lembaga musyawarah bagi masyarakat dan menjamin termuatnya aspirasi masyarakat dalam proses perencanaan pmbangunan di daerah yang bersangkutan.

\section{Metodologi Penelitian}

\section{Paradigma Penelitian.}

Dalam penelitian ini, menggunakan paradigma fakta sosial (Social facts paradigma). ${ }^{12}$ Penelitian ini pendekatan yang digunakan, pertama, adalah model ineractionist approach, yaitu untuk memahami bentuk peran serta masyarakat (PKL) terhadap pemanfaatan ruang dengan rencana tata ruang yang telah disusun. Kedua, adalah model rational approach yaitu untuk membangun pemahaman penafsiran sebagai landasan tinjauan kritis terhadap kebijakan penataan ruang. 
Dengan kata lain, penelitian ini katagori penelitian social legal research, yaitu ingin melihat efektifitas hukum (dalam hal ini hukum penataan ruang) di masyarakat.

\section{Lokasi Penelitian}

Penelitian ini dilakukan di Jalan Majapahit dan depan Stasiun Kota Baru Kota Malang dan sekitarnya.

\section{Jenis Dan Sumber Data}

Ada dua (2) jenis data kualitatif yang hendak dikumpulkan dalam penelitian ini yaitu : data primer dan data skunder. Untuk keperluan penelitian ini, ada 3 (tiga) sumber data sebagai sumber informasi, yaitu (a) aparat birokrasi yang berkopeten dengan penataan ruang, (b) masyarakat (PKL), dan (c) dokumen-dokumen resmi yang ada kaitannya dengan masalah penataan ruang. Penentuan informan dilakukan secara random sesuai dengan kepentingan dan keperluan analisis.

\section{Teknik Pengumpulan Data}

Pengumpulan data dalam penelitian ini melalui tiga (3) teknik yaitu : (1) teknik wawancara mendalam (depth intervieuw), (2) teknik observasi, dan (3) dokumentasi.

\section{Teknik Analisa Data}

Tahap analisis data dalam penelitian kualitatif, menurut Paton sebagaimana yang dikutif oleh Moleong ${ }^{13}$. Analisis data adalah proses penyusunan data agar dapat ditafsirkan.

Analisis data dalam penelitian ini dilakukan melalui model interaktif yaitu diperkenalkan oleh Miles \& Huberman, menurutnya untuk membangun suatu analisis data yang komprehensif dalam sebuah penelitian kualitatif, seharusnya berlangsung pada tiga siklus kegiatan, yaitu reduksi data, penyajian data, dan penarikan kesimpulan atau verifikasi. Ketiga kegiatan tersebut berlangsung sebagai sesuatu yang jalin menjalin. 


\section{Hasil Penelitian Dan Pembahasan}

\section{Dasar Pemikiran Pemda Melakukan Pembinaan PKL}

Dasar pemikiran Pemerintah Daerah mencanangkan pembinaan dan penataan kembali keberadaan Pedagang Kali Lima (PKL) di Jalan Majapahit dan depan Stasiun Kota Malang, yaitu: Pertama, tertuang dalam pola dasar pembangunan daerah, visi misi pembangunan Kota Malang, yaitu: Malang sebagai kota pendidikan, sebagai kota industri, dan sebagai kota pariwisata (Tri Bina Cita), Kedua, Malang sebagai kota besar kedua di Jawa Timur yang telah membawa perkembangan berbagai sektor ekonomi yang begitu cepat, salah satunya adalah sektor informal (PKL), Ketiga, berkembang pesatnya sektor ekonomi formal, keempat, krisis moneter yang betkepanjangan, telah mendorong masyarakat melakukan pilihan pekerjaan yang mudah dan tidak memerlukakan modal serta skill yang tinggi yaitu sebagai PKL.

Adapun dasar hukum pembinaan PKL Kota Malang adalah:

1. Peraturan Daerah Kotamadya Malang Daerah Tingkat II Malang No 11 Tahun 1984 tentang Ketertiban dan Kebersihan Kotamadya Malang. Di dalam pasal 3 dinyatakan bahwa: (1) dilarang menempatkan barang dan berjualan dijalan umum, kecuali mendapatkan ijin dari Kepala Daerah: (2)ijin yang dimaksud pada ayat (1) pasal ini diberikan setelah memenuhi syaratsyarat yang ditentukan; (3) Pemerintah Daerah akan mengatur lebih lanjut ketentuan-ketentuan tersebut pada ayat (1) dan ayat (2).

2. Peraturan Daerah Kotamadya Dati II Malang No 9 Tahun 1992 tentang Pengaturan dan Pembinaan Pedagang Kaki Lima di wilayah Kotamadya Malaqng Jo.Perda No 1 Tahun2000 Tentang Pengaturan dan Pembinaan Perdagangan Kaki Lima di Wilayah Kota Malang.

3. KeputusanWaliKotamadya Kepada Daerah Tingkat II Malang No 06 Tahun 1999 Tentang Tim PenataanKembali Pedagang Kaki Lima (PKL) Di AlunAlunPlasa Dan sekitarnya. Didalam pasal 2 dati Keputusan tersebut dinyatakan kepada fungsisemula yaitu sebagai tempat kawasan dantaman terbuka serta trotoar; (2)memberikan pelayanan dan informasi penataan penempatan pedagang kaki lima; (3) mengawasi dan menertibkan pelaksanaan penataan pedagangkaki lima; (4) melaporkan dan 
mempertangung -jawabkan pelaksanaan tugasnya pada Walikotamadya Kepada daerah.

4. Pengumuman Walikotamadya Kepada Daerah Tingkat II Malang No 188.55/04428.114/1999 tentang Penataan Pedagang Kaki Lima di sekitar Alun-Alun Plasa.

\section{Analisis Dan Interprestasi Data}

\section{a. Pola Pemanfaatan Lahan Untuk PKL}

Ada dua hal yang perlu dikaji mengenai pola pemanfaatan lahan oleh PKL yaitu: (a) pola pemanfaatan lahan untuk PKL; (b) faktor-faktor yang menyebabkan penyimpangan pemanfaatan lahan. Pertama, pengaturan lokasi untuk pedagang kaki lima (PKL) di dalam RTRW ditetapkan sebagai berikut; (1) pada kawasan pusat kota, keberadaan pedagang kaki lima akan dialokasikan pada sepanjang jalan Zainal Zakse dan Ade Irma Suryani untuk jenis perdagangan baju, sepatu dan perlengkapan sejenisnya;(2) pada jalan Pulosari, Gede, Rajekwesi, Bareng dan Brawijaya untuk jenis penjualan makanan dan minuman serta buah-buahan; (3) pada jalan Majapahit digunakan untuk perdagangan jenis buku, majalah dan Irian Jaya untuk jenis perdagangan barang bekas terutama untuk barang dari logam, onderdil mobil-motor ataupun keperluan lain yang terbuat dari bahan logam. Akan tetapi pada kondisi sekarang mengalami perkembangan pesat dan lokasinya tidak sesuai dengan rencana, seperti pasar buah mulai berkembang di Jl.Halmahera.

Melihat fakta tersebut, sebenarnya pengaturan lokasi PKL yang terdapat dalam RTRW secara yuridis bertentangan perundangan yang berlaku yaitu: (1) Asas dalam UU No 24 tahun 1992 (UU Penataan Ruang) dimana pemanfaatan ruang harus menjamin semua kepentingan secara terpadu, berdaya guna dan berhasil guna, serasi, selaras, seimbang dan berkelanjutan; (2) Peraturan Daerah Kota Malang No 11 Tahun 1984 tentang Ketertiban dan Kebersihan Kota Malang, dalam pasal 3 dinyatakan bahwa: (a) dilarang menempatkan barang dan berjualan di jalang umum, kecuali mendapatkan izin dari kepala daerah; (b) izin yang dimaksud pada ayat (1) pasal ini diberikan setelah memenuhi syarat-syarat yang ditentukan; (3) Peraturan Daerah Kota Malang No 9 Tahun 1992 tentang Pengaturan dan pembinaan Pedagang Kaki Lima di wilayah Kota Malang, Junto Perda No 1 Tahun 2000 Tentang "Pengaturan Dan Pembinaan PKL Di Wilayah Kota Malang". Dalam 
pasal 3 ayat (1) dinyatakan bahwa "setiap pedagang kaki lima dilarang melakukan kegiatan usahanya dijalan, trotoar, jalur hijau dan/atau fasilitas umum kecuali di kawasan tertentu yang ditetapkan lebih lanjut oleh kepala daerah"

Kalau merujuk teorinya Bruggink tentang keberlakuan faktual atau empiris kaidah hukum, bahwa kaidah hukum berlaku secara faktual atau efektif, jika para warga masyarakat, mematuhi kaidah hukum tersebut. Dari konsep ini, dapat dikatakan bahwa peraturan perundangan yang mengatur tentang PKL di Kota Malang belum berjalan secara efektif atau tidak memiliki keberlakuan faktual. Hal ini tercermin dari kebijakan pemerintah daerah yang menyalahi peratauran yaitu merelokasi PKL di depan Stasiun Kota Baru dan pemanfaaatan lahan oleh para PKL ditempat-tempat yang tidak sesuai dengan peruntukannya.

Namun kalau kita kaji secara lebih arif, keluhan yang timbul yang berkenaan dengan PKL yang sering disebutkan sebagai penyabab kemacetan lalu lintas, memperburuk keindahan kota hingga kerawanan situasi sosial ekonomis, sebenamya keberadaan PKL secara langsung maupun tidak langsung telah mendorong peningkatan kegiatan perdagangan, distribusi maupun pemasaran meskipun dalam jumlah yang relatif kecil. Sisi lain keberadaan PKL juga mampu meyerap tenaga kerja walaupun sebagai tenaga kerja yang tidak tetap.

Sedangkan masalah lokasi nampaknya merupakan masalah sentral yang melatar belakangi adanya keluhan-keluhan yang dilontarkan. Hal ini dikarenakan jalan dan trotoar sebagai jalan kondaraan dan pejalan kaki. Namun demikian kebutuhan akan lokasi bagi aktifitas pedagang kaki lima adalah merupakan hal yang logis. Tumpuhan aktivitas pedagang kaki lima memang lebih banyak kepada perdagangan fisik dan segala keterbatasan kemampuan yang dimilikinya telah mendorong mereka memilih lokasi yang strategis (untuk kelancaran pemasaran produknya). Persepsi PKL meliaht Jalan Majapahit merupakan tempat yang paling dekat dengan pusat kota, dengan harapan hasil produknya akan banyak yang membeli (usahanya lancar). Permasalahannya terletak pada kondisi bagaimana pengalokasian yang diperuntukkan bagi mereka, dan ini bukan berarti hanya menggiringnya kedalam suatu tempat tertentu saja, tetapi harus pula memperhatikan masalah kelancaran usahanya, dan yang harus diperhatikan dalam pemilihan relokasi PKL adalah kawasan yang seharusnya dilindungi seperti kawasan jalur Hijau, sebaiknya kegiatan pedagang kaki lima tidak di izinkan apalagi dikembangkan lebih lanjut. 
Mengenai faktor-faktor penyimpangan pemanfatan lahan untuk PKI dapat dianalisis dari teorinya Lawrence M. Friedman dan Robert B. Seidman.analisis kedua tokoh tersebut mengungkapkan bahwa efektifitas berlakunya peraturan perundang-undangan dapat dikaji dari faktor-faktor yang mempenganuhi atau isi hukum (legal subtansi), penegak/pelaksana hukum (legal stuctur) dan budaya hukum masyarakat (legal culture).

Dari komponen pembuatan peraturan perundangan (law makin proces), asas keterbukaan tata ruang (UU No. 24 tahun 1992), peran serta masyarakat dalam proses penyusunan RTRW (PP. No. 69 tahun 1996 dan keputusan Menteri dalam Negeri No 650/ 658/1985 serta Peraturan Menteri Dalam Negeri No 9 tahun 1998) dapat dijadikan acuan untuk menilai apakah proses RTRW tersebut baik atau tidak.

Proses penyusunan RTRW di Kota Malang secara yuridis dilaksanakan sebagai berikut:

1. setelah wali kota sebagai kepala daerah membentuk tim teknis maka ditunjuklah suatu konsultan untuk membuat rencana tata ruang. Dalam membuat rencana tata ruang ini pihak masyarakat dan instansi/swasta/ lembaga/forum/LSM memberikan masukan kepada konsultan agar dapat menghasilkan suatu rencana tata ruang yang baik.

2. setelah menghasilkan rekomendasi tata ruang kemudian diserahkan kepada Wali Kota untuk selanjutnya di bawa ke DPRD sehingga mendapatkan pengesahan dan rencana tersebut menjadi rancangan peraturan daerah.

3. rancangan pertaturan daerah tersebut kemudian dibawa ke gubernur dan melalui tim teknis yaitu Cipta Karya, Bappeda.BPN, rancangan peraturan daerah tersebut diteliti kembali bila disetujui di bawah Menteri Dalam Negeri untuk kemudian diteliti oleh Direktorat Jenderal Pembangunan Daerah dan bila disetujui maka keluar keputusan Menteri Dalam Negeri tersebut;

4. setelah adanya keputusan Menteri Dalam Negeri dikembalikan lagi kepada Walikota dan untuk selanjutnya Walikota akan mengeluarkan peraturan daerah (Perda).

Melihat proses penyusunan tersebut, nampaknya asas keterbukaan dan peran serta masyarakat belum dilaksanakan dengan sepenuhnya oleh Pemda (role occupan) masyarakat hanya dilibatkan sebetas pada saat seminar draft Rencana 


\section{4}

Tata Ruang Wilayah (RTRW). Dari temuan fakta dilapangan, menunjukkan proses penyusunan refisi rencana tata ruang Kota Malang terkesan "berlangsung lancar". Alasan Pemda (baca Bapeda) penyusunan revisi RTRW yang berlangsung singkat ini dikarenakan Bapeda dikejar target waktu untuk diadakan penyesahan oleh DPRD Kota Malang.

Dalam kerangka keterbukaan, pertama kalinya Pemda melakukan sosialisasi kepada masyarakat meliputi empat kegiatan, yaitu: melalui Radio, Koran, Penyebaran pamflet dan penyuluhan masyarakat pada setiap kecamatan, berdasar pengamatan dilapangan pelaksanaan sosialisasi ini nampaknya belum menyentuh dari tujuan yang sebenarnya yakni membangun tumbuhnya kesadaran masyarakt untuk memberikan masukan terhadap RTRW. Dengan kata lain secara formal proses sosialisasi telah dilaksanakan tetapi secara subtansial masyarakat belum mampu menangkap dari apa yang disosialisasikan Bapeda. Kurang mampunya masyarakat dalam menangkap maksud dari RTRW ini disebabkan dari sisi teknis pelaksanaan yang dilakukan oleh Pemda (Bappeda). Dari sisi waktu pelaksanaan talk show di radio dengan tenggang wanktu selama satu (1) jam dan tiga kali talk show belum dapat menyampaikan materi secara keseluruhan, serta banyak masyarakat yang tidak mengetahui terhadap adanya siaran tersebut. Sedang dari kegiatan penyuluhan kepada masyarakat yang dilakukan satu kali untuk masingmasing kecamatan nampaknya kurang berjalan secara efektif. Hal ini dapat dilihat dari penyuluh sendiri yang kuran memahami teknik komunikasi dengan baik sehingga dalam penyajian terkesan tergesa-gesa dan masyarakat akhirnya tidak memperhatikan. Begitu juga dari para peserta penyuluhan hanya terbatas pada perangkat desa, kecamatan dan tokoh-tokoh masyarakt tertentu yaitu dari unsur ketua RT (rukun tetangga) dan ketua RW ( rukun warga). Kurang efektifnya pelaksaan sosialisasi tersebut menjadikan kurangnya pemahaman masyarakat terhadap kewajiban yang harus dilakukan yakni memberikan kontrol terhadap tata ruang.

Kalau menujuk teori yang dikembangkan oleh Mr. Dr. AN. Bos yaitu : "Doktrin Politik" bagi legislator yang mempunyai kewajiban untuk berusaha menghasilkan masyarakat yang lebih baik merupakan kebajikan moral yang tidak bisa dipaksa untuk melakukannya sepanjang ia masih dalam jalur hukum. Nampaknya belum menjadi “etos kerja" bagi para legislator di Kota Malang begitu juga keberadaan institusi-institusi yang memberi kesempatan untuk mengerti tindakan-tindakan 
pemerintah secara kritis dan melakukan proses untuk menentangnya jika perlu. Dalam kerangka keterbukaan dan peran serta masyarakat pemerintah daerah seharusnya melakukan publik city yaitu pemerintah memberikan informasi tentang tindakan-tindakan kepada warga negara yang berkepentingan.

Kebiasan-kebiasan legislator dan warga negara untuk tidak melakukan publicity dan inspraak, yang menurut Friedman di karenakan budaya hukum (legal culture). Faktor budaya hukum, seperti keenganan para legislator dan para warga negara untuk melakukan tindaka, juga menjadi salah satu penyebab lemahnya kontrol masyarakat terhadap kebijakan Pemda sehingga banyak kebijakan tentang pemanfatan lahan yang tidak sesuai dengan peruntukannya. Kebijakan yang menyalahi peraturan itu nampak dari langkah-langkah penempatan para PKL, antar lain: (1) menempatkan PKL dilokasi jalan Trunojoyo ( jalan sepanjang Stasiun kereta api kota baru dengan ketentuan buka mulai jam 16.00 WIB s/d jam 22.00 WIB dan selesai berjualan tempat harus bersih semula; (2) menempatkan PKL dijalan Bondowoso (sebelah selatan ruko) dengan alasan lokasi sangat luas yang memungkinkan dapat menampung seluruh PKL yang ada, status tanah milik Pemda dan sifatnya bisa permanen.

Kebijakan pemda merelokasi PKL ditempat-tempat tertentu tidak terlepas dari makna atau pandagngan Pemda tentang keberadaan PKL. Teori Interaksionisme simbolik memandang pilihan tindakan manusia itu berkaitan dengan makna atau objek. Makna merupakan interpretasi yang diberikan seseorang atas suatu objek dan dalam suatu tindakan makna tersebut dipakai sebagai instrumen yang mengarahkan suatu tindakan. Pilihan tindakan berdasarkan atas makna suatu objek membawa relatifisme pandangan dalam berfikir ${ }^{14}$. Dalam kerangka demikian, misalnya kebijakan pemda yang merelokasi PKL ditempat-tempat tertentu untuk sementara waktu didasarkan pada pandangan pemda terhadap PKL yang berjualan sifatnya sementara yakni hanya mendekati tahun baru, lebaran Natal dan Idul Fitri serta untuk menghadapi kondisi krisis ekonomi, sehingga izin yang diberikan oleh pemda juga bersifat sementara. yaitu setelah leberan harus bersih kembali.

Namun realitanya, kebijakan setelah lebaran dan kondisi ckonomi sudah mulai pulih para PKL enggan untuk meninggalkan tempat tersebut dan pemda sendiri mengalami kesulitan untuk "membersihkan" $P K L$ dari tempat tersebut. Seharusnya pemda tidak melihat PKL sebagai pekerjaan seseorang untuk sementara waktu, 
tetapi harus melihat PKL sebagai "lembaga" yang keberadaannya sedang berakar di masyarakat dari dahulu hingga sekarang.

Sedang dari komponin subtansi, Peraturan Daerah Kota Malang No 2 tahun 1984 tentang ketertiban dan Kotamadya Malang khususnya pasal 3 (1) yang berbunyi " dilarang menempatkan barang dan berjualan dijalan umum kecuali mendapat ijin dari kepala daerah “.pasal 3 (1) konsep" kecuali mendapat ijin dari kepala daerah " sangat memberikan peluang kepada pemda untuk membuat kebijakan menyimpang terhadap pola pemanfaatan lahan untuk PKL.

Kecendrungan penyimpangan pemanfaatan lahan untuk PKL ini dari aspek non hukumnya yaitu dari aspek ekonomi juga memberikan hukuman konstitusi terhadap penyimpangan pemanfatan lahan. Aspek ekonomi ini nampak dari perkembangan Kota Malang dalam kegiatan ekonomi sekunder dan tersier (perdagangan dan jasa) telah meningkat dengan pesat dan cenderung lokasinya dipusat kota dan di jalan-jalan protokol tertentu. Semakin memusatnya kegiatan ekonomu di kota telah mendorong peningkatan kebutuhan akan pra-sarana dan sarana penunjang termasuk diantaranya adalah utility kota. Faktor ini pula yang telah memberikan konstribusi dan sebab-sebab penyimpangan terhadap pemanfatan lahan untuk pedagang kaki lima.

\section{Peran Serta Masyarakat Pedagang Kaki Lima (PKL) dalam Pemanfatan Ruang}

Mencermati rendahnya peran serta masyarakat (PKL) dalam pemanfatan ruang dalam bentuk: (1) memanfaatkan ruang untuk berjualan yang sesuai dengan perundang undangan, agama, adat dan kebiasaan yang berlaku, (2) titik bantuan pemikiran dan pertimbangan terhadap pemanfatan ruang, (3). Penyelangaraan kegiatan pembangunan berdasar rencana tata ruang, (4). Konsolidasi pemanfatan ruang,(5) perubahan atau konvensi pemanfaatna ruang yang sesuai dengan rencana tata ruang, (6) pemberian masukan untuk menetapkan lokasi pemanfaatan ruang, (7) kegiatan menjaga, memelihara dan meningkatkan kelestarian lingkungan dalam kaitan dengan pemanfaatan lingkungan, dapat dianalsis dari teorinya Seidman. Teori Seidman ${ }^{15}$ adalah hukum itu mempengaruhi pilihan tindakan manusia dalam dua cara yaitu secara langsung dan tidak langsung. Pertama, hukum mempengaruhi pilihan tindakan manusia secara langsung disebabkan oleh beberapa hal, yaitu: (a) 
individu yang bersangkutan merasa hukum itu merupakan perintah yang bersifat memaksa, (b) hukum itu memberikan perangsang yang harus diperhitungkan, (c) hukum itu benar sehingga perlu dipatuhi. Kedua, hukum mempengaruhi pilihan tindakan manusia secara tidak langsung karena individu memperhatikan dan mengikuti pola-pola perilaku yang dilakukan oleh orang lain secara berulang-ulang atau sudah melembaga dalam kehidupan masyarakat.

Merujuk teori tersebut di atas, behwa kegagalan hukum penataan ruang untuk mengeginar perilaku masyarakat untuk berperan serta dalam pemanfaatan ruang, menunjukkan bahwa Undang-undang Penataan Ruang No. 24 tahun 1992, dan peraturan lainnya belum mendapat legitimasi dari masyarakat, karena kesadaran hukum masyarakat tentang apa yang seharusnya dilakukan atau berbuat atau seharusnya tidak dilakukan atau berbuat (Mertokusumo) dalam kerangka pemanfaatan ruang masih rendah.

Kelemahan kesadaran hukum ini, menurut Munir ${ }^{16}$ dalam Disertasinya dan perkuliahan "Budaya Hukum" disebabkan oleh tidak adanya komunikasi hukum. Begitu juga berlakunya asas "setiap orang dianggap tahu undang-undang atau hukum yang berlaku" juga mempengaruhi kesadaran hukum masyarakat. Konsep kesadaran hukum masyarakat berdasar Simposium Nasional oleh badan Pembinaan Hukum Nasional (BPHN) tahun 1975, mencakup tiga hal, yaitu: (a) pengetahuan terhadap hukum, (b) penghayatan fungsi hukum, (c) ketaatan terhadap hukum.

Bertolak dari teori tersebut, dalam pemanfaatan ruang dapat dikatakan bahwa kesadaran hukum masyarakat (PKL) masih rendah, lebih disebabkan oleh tidak efektifnya pelaksanaan komunikasi hukum lewat sosialisasi. Hal ini tercermin dari pelaksanaan sosialisasi yang dilakukan oleh pemerintah daerah kepada masyarakat masih baru pertama kali.

Permasalahan berikutnya adalah bagaimana seseorang akan mampu mengetahui, memahami dan apalagi menaati hukum, kalau proses penyadaran sendiri hanya dilakukan dengan waktu relatif singkat. Dengan kata lain kurang mampunya masyarakat dalam menangkap maksud dari RT/RW ini, lebih disesbabkan dari sisi teknis pelaksanaan yang dilakukan oleh pemerintah daerah (Bappeda). Di sisi waktu pelaksanaan talk show di radio dengan tenggang waktu selama 1 (satu) jam dan 3 (tiga) kali talk show belum dapat mencapai materi secara keseluruhan, serta banyak masyarakat yang tidak mengetahui terhadap adanya siaran tersebut. Sedangkan dari kegiatan penyuluhan kepada masyarakat yang dilakukan satu kali untuk masing- 
masing kecamatan nampaknya juga kurang berjalan secara efektif. Hal ini dapat di lihat dari penyuluhan sendiri yang kurang memahami teknik komunikasi dengan baik sehingga dalam penyajian terkesan tergesa-gesa dan masyarakat akhirnya tidak memperhatikan. Bagitu juga dari para peserta penyuluhan hanya terbatas pada perangkat desa, kecamatan dan tokoh-tokoh masyarakat tertentu yaitu dari unsur Ketua RT (Rukun Tetangga) dan Ketua RW (Rukun Warga). Kurang efektifnya peaksanaan sosialisasi tersebut menyebabkan rendahnya pengetahuan dan pemahaman masyarakat tentang rencana tata ruang serta peruntukannya.

Begitu juga berlakunya asas hukum "Setiap orang dianggap tahu undangundang atau hukum yang berlaku" pada dasarnya kurang memadai apabila ditinjau dari perspektif usaha mewujudkan kedasaran hukum masyarakat. Hal ini dikarenakan kondisi masyarakat (PKL) sangat beragam baik dalam tingkat pendidikan, ekonomi maupun budaya. Lebih-lebih budaya masyarakat (PKL) untuk membaca dan rasa ingin tahu yang masih rendah, juga menyebabkan lemahnya masyarakat menangkap maksud dari pamflet-pamflet yang dipasang, koran Malang Post, talk show di radio dan penyuluhan yang dilaksanakan oleh pemerintah daerah.

Aspek lain untuk melihat permasalahan mengapa masyarakat (PKL) masih tetap saja berjualan di sekitar Jalan Majapahit dan depan Station Kota Malang serta jumlahnyapun semakin bertambah serta lokasinya semakin meluas disepanjang jalan dan trotoar. Untuk memahami realitas tersebut, dari aspek struktur nampaknya pemerintah daerah "tidak konsisten" di dalam menegakkan hukum (law inforcement) terhadap para PKL. Inkonsisten pemerintah daerah ini dimanifestasikan dalam bentuk: (a) tidak melakukan penertiban terhadap PKL, (b) pemerintah daerah masih menarik retribusi (resmi dan tidak resmi) kepada PKL walaupun lokasi PKL menyalahi peraturan sebesar Rp. 40.000 ,- pertenda setiap bulan termasuk pembayaran listrik, (c) pemerintah daerah masih merelokasi PKL di tempat-tempat yang tidak sesuai dengan peruntukannya, (d) pemerintah daerah memberikan fasilitas kredit berupa tenda-tenda untuk berjualan, satu tendanya berkisar seharga Rp. 1. 250.000,- (satu juta dua ratus lima puluh ribu rupiah). Rendahnya penegakan hukum (law inforcement) tersebut salah satunya disebabkan pandangan pemerintah daerah yang melibatkan PKL sebagai pekerjaan sementara (batu loncatan). Begitu juga eforia reformasi yang sedang berlangsung di negara ini, telah menjadikan pemerintah daerah menjadi gamang dalam mengambil setiap keputusan khsusnya tentang PKL. 
Secara rinci sikap masyarakat pada era reformasi menurut Sodiki digambarkan sebagai berikut: (a) masyarakat kurang mempercayai hukum sebagai sarana yang dapat memberikan rasa keadilan. Terbukti bahwa sebagian aparat pemerintah yang tengah berkuasa telah melakukan perbuatan tercela, memperkaya diri secara melawan hukum tetapi seolah "legal" di mata hukum, terbukti pada lokasi (tenda) yang berada pada sisi paling depan dikuasai oleh aparat (oknum) pemerintah kota, seharusnya di serahkan kepada PKL, (b) jika masyarakat melakukan tuntutan terhadap pemerintah berdasarkan hukum di muka pengadilan dan kemudian penguasa dikalahkan, jarang sekali penguasa menaati putusan peradilan tersebut, misal dalam perkara peradilan tata usaha negara, (c) kekuasaan peradilan blended dengan kekuasaan pemerintah, oleh sebab itu sulit mengharapkan suatu sikap dan pendirian yang tidak memihak dari peradilan, kecuali hakim yang mempunyai kredibilitas tinggi, (d) sikap penguasa yang mendasarkan diri pada legalitas formal, seringkali bertabrakan dengan sikap masyarakat yang tidak mendukung legitimasinya, artinya ada kesenjangan antara legalitas dengan legitimasi, (e) kesenjangan antara legalitas dan legitimasi hukum yang demikian besar serta turunnya wibawa hukum menimbulkan kegamangan bertindak dari aparat penegak hukum terhadap pelanggaran hukum sekalipun tersebut kuat legitimasinya, (f) dalam suasana ketidakpastian dan tekanan ekonomi, masyarakat mencari ukuran rasa keadilan lain, bukan lagi bersumber pada undang-undang atau keputusan pemerintah, tetapi berdasarkan penafsiran sesaat atas fenomina yang terjadi. Bahkan seringkali bukan atas dasar adil atau tidak adil tetapi lebih mengedepankan upaya pemenuhan kebutahan nyata sehari-hari (need).

Pandangan pedagang kaki lima (PKL), mengungkapkan bahwa keberadaannya adalah "legal" atau resmi. Konsep legal mereka adalah: pertama, Pemda masih menarik retribusi maupun pungutan tidak resmi; kedua, Pemda masih merelokasi PKL di tempat-tempat lain seperti di depan Stasiun Kereta Api Kota Baru; ketiga, Pemda masih memberikan fasilitas kredit dari Bank Jatim berupa tenda-tenda untuk berjualan.

Teori lain yang dapat dijadikan rujukan adalah teori interaksionisme simbolik yaitu manusia tidak dilihat sebagai produk yang ditentukan struktur, tetapi merupakan manusia (aktor) yang bebas. Menurut teori ini, kebudayaan, sistem sosial, stratifikasi sosial tidak menentukan tindakan manusia, tetapi mengakui bahwa kebudayaan itu bersifat membentuk kondisi-kondisi bagi tindakan manusia ${ }^{17}$. 
Ketika di tanya apakah mereka (PKL) mengetahui kalau berjualan di JI. Majapahit sekitanya dilarang oleh Pemerintah Daerah (Pemda). Pada umumnya mereka mengetahui, karena disamping di Jl. Majapahit sudah tertulis dilarang untuk tidak berjualan disini, tetapi mereka tetap berjualan di sini. Pandangan mereka adalah: pertama, kalau tidak jualan kami tidak bisa makan; kedua, di J. Majapahit banyak di kunjungi masyarakat. Ketiga, kami sudah melakukan izin kepada Pemda maupun kepada koordinator PKL; keempat, kami sudah membayar uang retribusi (ada yang resmi dan ada yang tidak resmi);dan kelima, kami mendapatkan kredit dari Bank Jatim yang diwujudkan dalam bentuk tenda-tenda untuk berjualan.

Dengan pandangan tersebut, $\mathrm{PKL}$ menganggap apa yang dilakukan berjualan di jalan Majapahit dan depan Stasiun Kota Baru Malang ini adalah sah atau diperbolehkan Pemda. Sedangkan pandangan mereka mengapa mereka banyak tidak mau dipindahkan oleh Walikota Malang (Pak Suyitno) ke tempat lain, mereka menjawab "dateng mriki sing thiyange kathah mowon radi sephen, napa maleh wonthen panggenan lintu" (disini yang banyak orangnya saja agak sepi, apalagi di tempat lain).pandangan PKL ini semakin meneguhkan pandangan Sodiki bahwa: "dalam suasana ketidak pastian dan tekanan ekonomi, masyarakat mencari ukuran rasa keadilan lain, bukan bersumber pada undang-undang atas keputusan pemerintah, tetapi berdasarkan penafsiran sesaat atas fenomena yang terjadi. Bahkan seringkali bukan atas dasar adil atau tidak adil, tetapi lebih mengedepankan upaya pemenuhan kebutuhan nyata sehari-hari (need).

Sedangkan terkait dengan kebijakan Walikota tentang tendanisasi di depan Stasiun Kereta Api Kota Baru dengan ketentuan bongkar pasang (buka jam 16.00 $\mathrm{s} / \mathrm{d}$ jam 22.00WIB) tidak dijalankan. Pandangan mereka bahwa kebijakan Pak Yit itutidak praktis, karena disamping tendanya terbuat dari besi, juga karena keengganan untuk melakukan bongkar pasang. Realita tersebut, menggambarkan peranan kultur masyarakat juga mewarnai sebab-sebab rendahnya peran serta masyarakat (PKL) dalam pemanfaatan lahan yang sesuai dengan peruntukannya. Alasan tidak praktis, tidak efisien dan enggan" menunjukan mentalitas yang suka mengabaikan tanggung jawab, budaya nerabas, dan sifat tidak disiplin. 


\section{Penutup}

\section{a. Kesimpulan.}

Dengan melihat fakta, menunjukkan pengaturan lokasi PKL yang terdapat dalam RTRW secara yurudis bertentangan dengan peraturan perundang-undangan yang berlaku, yaitu: UU No. 24 Tahun 1992 tentang Penataan Ruang, Perda Kota Malang No. 11 Tahun 1984, tentang Ketertiban dan Kebersihan Kota Malang, Perda No. 9 Tahun 1992 tentang Pengaturan dan Pembinaan Pedagang Kaki Lima di wilayah Kota Malang, Juncto Perda No. 1 Tahun 2000 tentang Pengaturan dan Pembinaan PKL di wilayah Kota Malang. Sehingga menimbulkan konflik kepentingan.

Adapun yang menjadi faktor penyimpangan pemanfaatan lahan untuk PKL dari aspek struktur, antara lain :

1. Pemda sebagai rule occupant kurang melibatkan masyarakat dalam proses penyusunan RTRW;

2. Sebagai komponen substansi, dengan pasal 3 (1) Perda No. 11 Tahun 1984 , sangat memberi peluang kepada Pemda untuk membuat kebijakan penyimpangan terhadap pola pemanfaatan lahan untuk PKL;

3. Pemda tidak konsisten di dalam menegakkan hukum (low inforcement) terhadap PKL. Begitu juga dengan ada eforia reformasi, Pemda menjadi gamang dalam mengambil setiap keputusan khususnya tentang PKL seolaholah sah (kuasi legal).

\section{b. Saran-Saran.}

Berdasarkan hasil temuan dilapangan, penulis perlu merekondasikan perlunya Pemda bersama masyarakat untuk segera merumuskan konsep rencana pemanfaatan lahan untuk PKL pada umumnya. Dilakukan dengan cara komunikasi hukum dengan baik antara instansi, masyarakat, swasta dan lainnya yang berkompeten. Dengan demikian produktivitas manajemen kota dapat diwujudkan.

Menyikapi keberadaan PKL tersebut, hendaknya Pemda berani mengambil sikap untuk menegakan hukum dengan baik (law enforment) yakni konsisten dalam 
membuat kebijakan terhadap PKL. Reformasi jangan dijadikan alasan aparat takut bertindak terhadap pihak yang melanggar aturan.

\section{Endnotes:}

1. Suyanto, Bagong, 1996. Pembangunan Kota dan Sengketa Tanah, Prisma, September, hal 38

2 Ibid, hal. 40

3 Yamin, Bun Ramto, tt. Dalam makalah : "Pola Kebijakan dalam Sistem Pengelolaan Kota, hal. 18

4 Boedi Harsono, 2000. Hukum Agraria Indonesia : Sejarah Pembentukan Undang-Undang Pokok Agraria, Isi dan Pelaksanaannya, Jilid.I, Edisi Revisi, Djembatan, Jakarta, hal. 536

5 Kuswahyono. Imam, 1999. Bunga Rampai Politik dan Hukum Agraria Di Indonesia, UM Press, Malang. Hal. 94

6 Muzakir, 1999. Tesis, Partisifasi Masyarakat Dalam Perencanaan Dan Pelaksanaan Pembangunan, Program Pascasarjana Universitas Brawijaya, Malang, hal. 53

7 Passaribu, L.L B. Sinanjuntak, 1986, Sosiologi Pembangunan, Tarsito, bandung, hal. 32

8 Munir, Mochamad, 1997. Disertai Penggunaan Pengadilan Negeri Sebagai Lembaga Untuk Menyelesaikan Sengketa Dalam Masyarakat (Kasus penyelesaian sengketa yang berkaitan dengan tanah dalam masyarakat di Kabupaten Baqngkalan Madura), Universitas Airlangga, hal. 48

9 Soemitro, Hanitiyo Rony, 1985. Studi Hukum Dan Masyarakat, PT. Alumni, Bandung, him. 75

10 Seidman, Robert B., 1978. The State And Development, ST. martin's Preses New York, Cambrudge, Massachusetts, hlm. 35

11 Fauzi Noer, 2000, Otonomi Daerah dan Sengketa Tamah, Lapera Pustaka utama, Yogyakarta, hlm. 175-177

12 Durkheim, dalam Rizer, George, 1972, Sociology : Multiple Paradigma Science (terjemahan Alimanda, 1985. Sosiologi Ilmu Pengetahuan Berparadigma Ganda), Rajawali Press, Jakarta, 16-17

13 Moleong, Lexy, 2000, Metode Penelitian Kualitatif, Remaja Rosdakarya, Bandung, hlm. 103

14 Munir, Mochamad, 1997. Disertai Penggunaan Pengadilan Negeri Sebagai Lembaga Untuk Menyelesaikan Sengketa Dalam Masyarakat (Kasus penyelesaian sengketa 
yang berkaitan dengan tanah dalam masyarakat di Kabupaten Baqngkalan Madura),

Universitas Airlangga, hlm. 67

15 Ibid, hlm. 54

16 Ibid, hlm. 49

17 Poloma, dalam Munir, Op.Cit. hlm. 67

\section{Bibliography}

Boedi Harsono, 2000. Hukum Agraria Indonesia : Sejarah Pembentukan UndangUndang Pokok Agraria, Isi dan Pelaksanaannya, Jilid.I, Edisi Revisi, Djembatan, Jakarta.

Fauzi Noer, 2000, Otonomi Daerah dan Sengketa Tanah, Lapera Pustaka utama, Yogyakarta

Friedman M. Lawrence, 1969. On Legal Development, Rutgers Law Review, Diterjemahkan Oleh Racmadi Djoko Soemadio, Dalam Hukum Dan Masyarakat, Kumpulan Bahan Bacaan, Pusat Studi Hukum \& Pembangunan, FH Universitas Air Langga, Surabaya, 1977.

Informasi Hukum Pertanahan Yang Berkaitan Dengan Penataan Ruang, 1995/ 1996. Badan Pertanahan Nasional Proyek Pengembangan Hukum Pertanahan

Kuswahyono. Imam, 1999. Bunga Rampai Politik dan Hukum Agraria Di Indonesia, UM Press, Malang.

Laporan Fakta Dan Analisa, 2000. Rencana Penataan Pedagang Kaki Lima Kotamadya Dati Malang, Kerjasama Bappeda Dengan Pusat Studi Kependudukan Hukum, CV. Rajawali, Jakarta.

Moleong, Lexy, 2000, Metode Penelitian Kualitatif, Remaja Rosdakarya, Bandung.

Munir, Mochamad, 1997. Disertai Penggunaan Pengadilan Negeri Sebagai Lembaga Untuk Menyelesaikan Sengketa Dalam Masyarakat (Kasus penyelesaian sengketa yang berkaitan dengan tanah dalam masyarakat di Kabupaten Baqngkalan Madura), Universitas Airlangga.

Muzakir, 1999. Tesis, Partisifasi Masyarakat Dalam Perencanaan Dan Pelaksanaan Pembangunan, Program Pascasarjana Universitas Brawijaya, Malang.

Ulul Albab, Vol. 4 No. 1, 2002 


\section{Musleh Hamy}

Passaribu, L.L B. Simanjuntak, 1986, Sosiologi Pembangunan, Tarsito, bandung. Rahardjo. Satjipto, 1979. Pemanfaatan Ilmu Sosial Bagi Pengembangan Ilmu Hukum, Alumni, Bandung.

—, 1986. Hukum dan Masyarakat, PT. Angkasa, Bandung.

Rizer, George, 1972, Sociology : Multiple Paradigma Science (terjemahan Alimanda, 1985. Sosiologi Ilmu Pengetahuan Berparadigma Ganda), Rajawali Press, Jakarta.

Seidman, Robert B., 1978. The State And Development, ST. martin's Preses New York, Cambrudge, Massachusetts.

Soemitro, Hanitiyo Rony, Studi Hukum Dan Masyarakat, PT. Alumni, Bandung Suyanto, Bagong, 1996. Pembangunan Kota dan Sengketa Tanah, Prisma, September, hal 37-40.

Yamin, Bun Ramto, tt. Dalam makalah : "Pola Kebijakan dalam Sistem Pengelolaan Kota". 